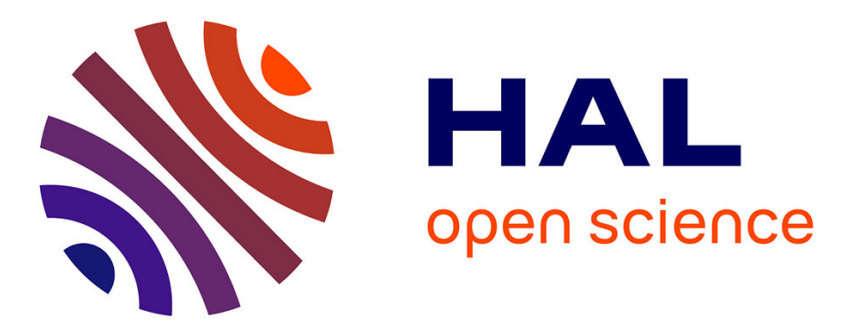

\title{
Comparison of catchment and network delineation approaches in complex suburban environments. Application to the Chaudanne catchment, France
}

S. Jankowfsky, F. Branger, Isabelle Braud, J. Gironas, F. Rodriguez

\section{- To cite this version:}

S. Jankowfsky, F. Branger, Isabelle Braud, J. Gironas, F. Rodriguez. Comparison of catchment and network delineation approaches in complex suburban environments. Application to the Chaudanne catchment, France. Hydrological Processes, 2013, 27 (25), p. 3747 - p. 3761. 10.1002/hyp.9506 . hal-00925688

\section{HAL Id: hal-00925688 \\ https://hal.science/hal-00925688}

Submitted on 8 Jan 2014

HAL is a multi-disciplinary open access archive for the deposit and dissemination of scientific research documents, whether they are published or not. The documents may come from teaching and research institutions in France or abroad, or from public or private research centers.
L'archive ouverte pluridisciplinaire HAL, est destinée au dépôt et à la diffusion de documents scientifiques de niveau recherche, publiés ou non, émanant des établissements d'enseignement et de recherche français ou étrangers, des laboratoires publics ou privés. 


\title{
Comparison of catchment and network delineation approaches in complex suburban environments. Application to the Chaudanne catchment, France.
}

\author{
Sonja Jankowfsky ${ }^{\mathrm{a}, \mathrm{c}}, *$ Flora Branger $^{\mathrm{a}}$, Isabelle Braud ${ }^{\mathrm{a}}$, Jorge Gironás ${ }^{\mathrm{b}}$ and Fabrice Rodriguez ${ }^{\mathrm{c}}$ \\ a) IRSTEA, Hydrology-Hydraulics Research Unit, Lyon, France \\ b) Departamento de Ingeniería Hidráulica y Ambiental, Pontificia Universidad Católica de Chile, \\ Santiago, Chile \\ c) LUNAM Université, IFSTTAR, GER, Bouguenais, France
}

\begin{abstract}
:
Suburban areas are subject to strong anthropogenic modifications, which can influence hydrological processes. Sewer systems, ditches, sewer overflow devices and retention basins are introduced and large surface areas are sealed off. The knowledge of accurate flow paths and watershed boundaries in these suburban areas is important for storm water management, hydrological modelling and hydrological data analysis. This study proposes a new method for the determination of the drainage network based on time efficient field investigations and integration of sewer system maps into the drainage network for small catchments of up to $10 \mathrm{~km}^{2}$. A new method is also proposed for the delineation of subcatchments and thus the catchment area. The subcatchments are delineated using a combination of an object-oriented approach in the urban zone and GIS based terrain analysis with flow direction forcing in the rural zone. The method is applied to the Chaudanne catchment, which belongs to the Yzeron river network, and is located in the suburban area of Lyon, France. The resulting subcatchment map gives information about subcatchment response and contribution. The method is compared to six other automatic catchment delineation methods based on stream burning, flow direction forcing and calculation of subcatchments for inlet points. None of the automatic methods could correctly represent the catchment area and flow paths observed in the field. The watershed area calculated with these methods differs by as much as $25 \%$ from the area computed with the new method.
\end{abstract}

KEY WORDS suburban drainage network, watershed delineation, sewer network, artificial ditches, storm water management, subcatchments

\section{INTRODUCTION}

Growing urbanisation mainly affects suburban areas, which are subject to fast changes due to human activity (Douglas, 2006). Anthropogenic alterations affecting the hydrological processes in these areas include land-use changes, increase of impervious areas and artificial channels (Graf, 1977), and alterations to the natural drainage regime. These modifications increase the peak discharge and accelerate the catchment response (Zheng and Baetz, 1999). They also raise overland flow causing erosion problems (Jones et al., 2000), and reduce infiltration, groundwater recharge and river base flow. Water quality is equally affected by sewer overflows and urban pollutants being washed from the surface (Niemczynowicz, 1999). A good understanding of the hydrological functioning of suburban areas can contribute to reducing the mentioned risks and improving the overall water management as natural land is urbanized. In particular, in depth knowledge about the drainage system and contributing areas is relevant for several applications in drainage and storm water management (e.g. sizing and location of sewer pipes and retention basins, and construction of hydrological models). Moreover, information about catchment response and pollution risks can be deduced from the land-use properties of contributing areas. However, despite increasing data availability, the determination of drainage networks and catchment borders remains a difficult task in suburban areas, due to their heterogeneity. These areas consist of a mix of purely natural areas without anthropogenic influence, rural areas with dispersed settlements and urban areas, 
where most of the ground is occupied by built-up cadastral units and natural surfaces are reduced to spots in urban terrain.

In natural areas, digital elevation models (DEMs) and geographical information systems (GIS) have allowed the implementation of algorithms for automatic watershed delineation (e.g. O'Callaghan and Mark, 1984; Jenson and Domingue, 1988; Lea, 1992; Costa-Cabral and Burges, 1994, Tarboton, 1997). The most commonly used is the d8 flow direction algorithm (O'Callaghan and Mark, 1984), in which the flow direction follows the steepest gradient towards one of eight neighbours. These algorithms are combined with routines to remove sinks, accumulate the flow, extract the stream network and delineate the watershed and subcatchments. Many studies have improved erroneous watershed delineations in flat areas with missing topographic details (e.g. Garbrecht and Martz, 1997; Augusto et al., 2009). Other aspects to be carefully addressed when computing watershed delineation include the precision and minimum resolution of DEMs (Quinn et al., 1991; Nie et al., 2002; Hammond and Han, 2006), and the threshold value of upstream contributing area to determine the stream network. If river network maps are available, this problem can be overcome by using stream burning methods (Maidment, 1996; Saunders, 2000), surface reconditioning (Hutchinson, 1989; Hellweger, 1997) or flow direction forcing methods (Kenny and Matthews, 2005). All of these three methods improve catchment delineation (Callow et al. 2007; Kenny and Matthews, 2005). Stream burning considers decreases in the elevation of known stream grid cells prior to computing flow directions. Surface reconditioning reduces the elevation of known stream grid cells and cells within a buffer zone around the river network to obtain a smooth slope towards the streams. For the flow direction forcing, the stream network is integrated into the DEM derived flow direction matrix instead of directly altering the DEM (Kenny and Matthews, 2005). Stream burning can lead to watershed distortions (Saunders, 2000) and the creation of parallel streams (Hellweger, 1997). Furthermore, the calculated catchment area depends on the burn depth (Callow et al., 2007). Kenny and Matthews (2005) and Callow et al. (2007) showed that flow direction forcing and surface reconditioning perform better than stream burning. Overall, automatic methods usually result in satisfactory watershed delineation and drainage networks in natural areas when carefully applied (Fried, et al. 2000).

In areas under urban influence flow does not always follow topography (Djokic and Maidment, 1991; Smith and Vidmar, 1994) due to the presence of streets, buildings and underground sewer pipes (Denver Council of Governments, 1969; Djordjevic et al., 1999; Smith M.B., 2006). Thus, in most cases drainage patterns and catchment areas cannot be deduced from pure terrain analysis (Djokic and Maidment, 1991; Smith 1993; Doan 2000), even if a number of studies continue to do so (Choi et al., 2003 and 2005; Zheng and Baetz, 1999; Runman et al., 2005).

Different methods have been proposed to account for the impact of anthropogenic flow paths on the catchment hydrology. In rural areas, a Light Detection And Ranging (LiDAR) derived raster representation of the DEM with a fine resolution (e.g. $1 \mathrm{~m}$ ) can already reveal most of the anthropogenic objects like streets and ditches (Murphy et al., 2008). However underground pipes and culvert crossings cannot be detected. Murphy et al. (2008) proposed to integrate culvert crossings manually into the LiDAR derived DEM. Even with integrating field mapped culvert crossings into a 1m-resolution LiDAR DEM Sarrazin et al. (2012) only detected up to $66 \%$ of the connected drainage network in a rural setting.

The integration of artificial objects as hydrological correction can also be seen in several other studies based on DEMs with a coarser resolution. Streams, streets and sewers are burned in urban areas (e.g. Lhomme et al., 2004, Gironás et al., 2010), or elevation of cells corresponding to buildings are raised (Elgy, 1993; Zech et al., 1994; Nie et al., 2002). The burn depth is usually constant and varies for each study. For urban areas, Gironás et al. (2010) 
developed a method in which the elevation of streets and pipes is used for determining variable burn depths. They compared this method to a representation where only streets are burned using variable depth while the complete drainage network (natural channels and sewer pipes) is represented in a separate vector layer connected to the surface through defined inlets. They concluded that variable burn depths result in more realistic catchment borders than using a constant burn depth or the raw DEM. Instead of modifying the DEM, Smith and Vidmar (1994) and Kenny and Matthews (2005) forced the flow direction grid to follow the street network. In rural areas, Duke et al. $(2003,2006)$ integrated ancillary data of artificial drainage elements into DEMs. They classified roads as flat, raised and with ditches, and included information from road cross-sections into the DEM. Road data and location of irrigation channels were used to create forced flow direction grids, in which cross-flow patterns due to siphons, flumes, culverts and split flow elements were also included. They defined dead ends in flow paths and disconnected the corresponding contributing areas from the watershed. Resulting watershed limits were more realistic than those obtained using the d8 algorithm.

Djokic and Maidment (1991) manually incorporated anthropogenic objects into a Triangular Irregular Network (TIN) representation. Bocher and Martin (2009) are developing an application for the TANATO2 model (Bocher, 2005) to automatically integrate artificial objects in the TIN representation. Carluer and Marsily (2004) integrated man-made networks into a model mesh consisting of contours and streamlines (Moore and Grayson, 1991; Vertessy et al., 1993) in a rural setting. However, the integration did not change the catchment borders. Hammond and Han (2006) and MacNutt et al. (2004) combined automatic catchment delineation with manual delineation based on maps including artificial features. For urban areas, an object oriented approach, where single cadastral units are connected to the closest and lowest sewer pipe was adapted in storm water modelling (Greene and Cruise, 1995; Mitchell and Diaper, 2005; Rodriguez et al. 2003, 2005, 2008). Object oriented refers here to spatial objects as opposite to a pixel approach and not to the programming design.

None of the previous studies and methods was specifically developed for suburban areas, where slow-growing sewer networks of different types (i.e. urban and rural) coexist. Such mixture of elements does not facilitate the precise identification of the integrated drainage system in suburban catchments. Narrow ditches in rural areas are not easily captured from aerial photographs or DEMs, and underground sewer pipes cannot be detected by DEMs. Detailed sewer data are necessary for the object oriented approach and stream burning. However, these data, which are mostly gathered during the installation of the pipes, are often out of date or consider the wastewater system only. Moreover, the effect of flow conditions typical of urban systems, on catchment delineation is not taken into account by the traditional methods previously discussed. This includes sewer overflow and pumped networks. The approach of Duke et al. $(2003,2006)$ seems to be a good solution for rural areas, but it does not include underground sewer pipes either. Furthermore, detailed field campaigns are necessary to derive the road cross sections. Finally, a manual integration of a significant number of anthropogenic objects into the watershed delineation can be quite tedious, especially in strongly urbanized locations.

In this study, we propose and evaluate a method particularly designed for suburban areas which combine the DEM based methods more adapted to natural zones, and object-oriented methods, which are more applicable to urban settings. The new method allows the determination of the rainwater drainage network based on data analysis and time efficient field investigations for small (up to $10 \mathrm{~km}^{2}$ ) suburban catchments with multiple outlets. The data analysis includes the differentiation between combined, separated and ditch networks and the integration of sewer overflow devices and pumping stations. The outline of the paper is as follows: In the materials and methods section we describe the relevant hydrological objects in suburban areas for network delineation, as well as the necessary data and general hypotheses. 
We also present the methodology for drainage network determination and subcatchment delineation. Next, the method is applied to a study area, and compared to six other catchment delineation methods. Finally, we discuss the different methods and present our main conclusions.

\section{MATERIALS AND METHODS}

The method is structured in three principal parts (see Figure 1). In the first step, a preliminary catchment border has to be defined in order to better target the field work. For this, three substeps, referred to as $\mathrm{A}$ to $\mathrm{C}$ in Figure 1, are necessary. They are further explained in the following text. The second step consists of the drainage network determination and results in the final drainage network. This is taken as input for step three in which the urban and rural subcatchments are delineated. The method results in the final subcatchment map. For a better understanding the different steps will be referenced as $1 \mathrm{~A}$ to $3 \mathrm{~B}$ in the following text.

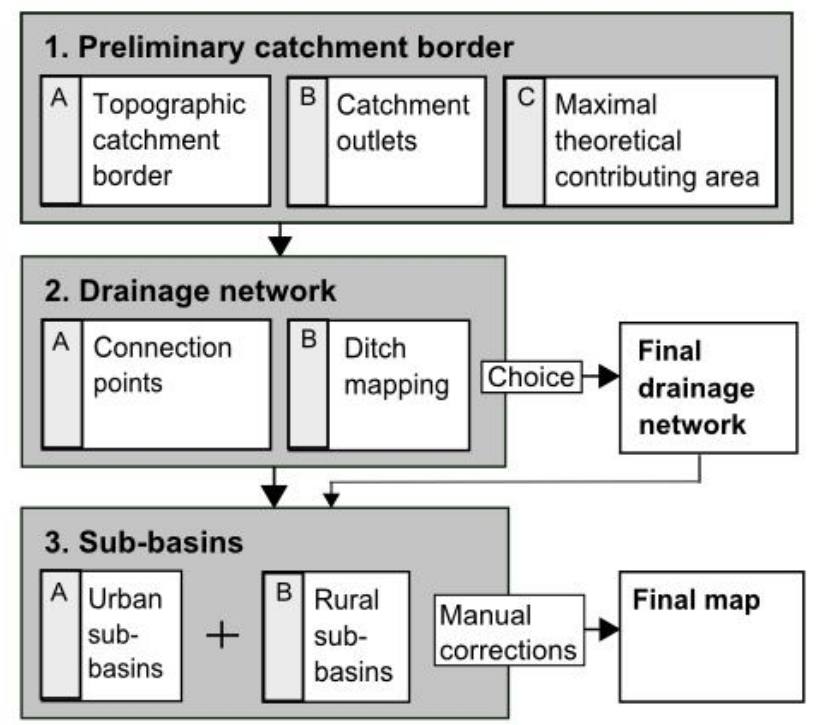

Figure 1: Scheme of the proposed method. The final drainage network and the final map represent the results of the described method. The final drainage network is necessary as input for step 3.

\section{General hypotheses}

This method builds on the assumption that subsurface flow follows topography. This means that there are no underground source or sink terms. In case of a known discrepancy with this assumption, the resulting catchment boundary should be adapted manually. Only rain water is considered for the catchment delineation; waste water and drinking water are not considered. The method applies to small multi- or single outlet catchments $\left(1-10 \mathrm{~km}^{2}\right)$.

\section{Description of hydrological objects relevant to network delineation in suburban areas}

The drainage network in suburban areas can consist of the following network types:

- The combined sewer system evacuates waste and rainwater in the same pipe system towards a waste water treatment plant (WWTP). Some parts of the network can be connected to a pumping station in order to direct all water, even against topography, towards the WWTP. In case of surcharge the network can be connected via storm water overflow devices to the natural river. If no storm water overflow device is installed for extreme rainfall events, the water will flow out of the manholes onto the street. In this study only sewer overflow devices are considered. 
- The separated sewer system consists of two unconnected rain and waste water networks. The rainwater network is often directly connected to the natural river, whereas the waste water flows to the WWTP. Retention or infiltration basins and oil water solid separators are sometimes located upstream of rain water injection points to the natural river.

- Roads in rural areas can function as corridors, barriers, sinks or sources (Jones et al., 2000). They are often sided by ditches which intercept surface runoff. The ditches can be connected to the natural river network or end in a dead end (Duke et al., 2006). In this study we only consider the corridor effect of connected ditches.

- Road independent artificial ditches in rural areas might be used for irrigation or drainage purposes.

- The natural river and lake network.

\section{Input data}

Some data are required and additional data can also be useful for the determination of drainage network and subcatchment delineation. A DEM is essential and the higher its resolution, the better the results (Vaze et al., 2010). Either aerial photographs, cadastre or detailed land use maps are required; they must correspond to the time period of interest, as suburban areas can change quickly. A map of the river network, preferably one which includes temporary reaches, and a topographic map can be helpful for the field work. All the maps must be digitized and georeferenced. Furthermore, all possible information about the drainage network is useful. This means maps of the sewer network, including flow directions, depth and slope of the pipes and information about the kind of network, the location of sewer overflow devices, pumping stations and retention basins. Information about ditches and rainwater drainage networks is gathered by means of field work here. The amount of field work is reduced if a large number of digital information is available. The contact with local authorities can provide further data and information about intended building projects and modifications of the sewer system.

\section{Determination of preliminary catchment border and catchment outlets}

A preliminary topographic catchment border (1A in Figure 1) for the river of concern has to be determined in order to better target the area for field investigations. This limit determines the area in which all water converge naturally towards the same river (Figure 2). The topographic catchment border can be calculated using standard terrain analysis methods based on DEMs, which are implemented in most GIS softwares. At this step, a drainage network based on the topography of the catchment is also calculated.

Suburban catchments equipped with a sewer system connected to a WWTP outside the topographic catchment border have at least two catchment outlets (1B): the natural river and the pipe towards the WWTP (Figure 2). In some cases, additional overflow devices towards other sewer systems can be installed. These outlets have to be determined in order to get a downstream catchment limit. In most cases, a measurement station at the natural river or a confluence will define the river outlet. The sewer system outlets are then determined in reference to this natural outlet. All sewer pipes leading outside the catchment, which are located downstream of the last connection to the natural river are regarded as outlets, refer to Figure 2.

After determining the catchment outlets, a first approximate catchment border including the urban zones can be determined. This area should encompass the whole connected sewer system (combined and separated) upstream of the catchment outlets, see Figure 2. Thus, it represents the maximal theoretical contributing area (1C) and limits the area of interest for the next steps. 


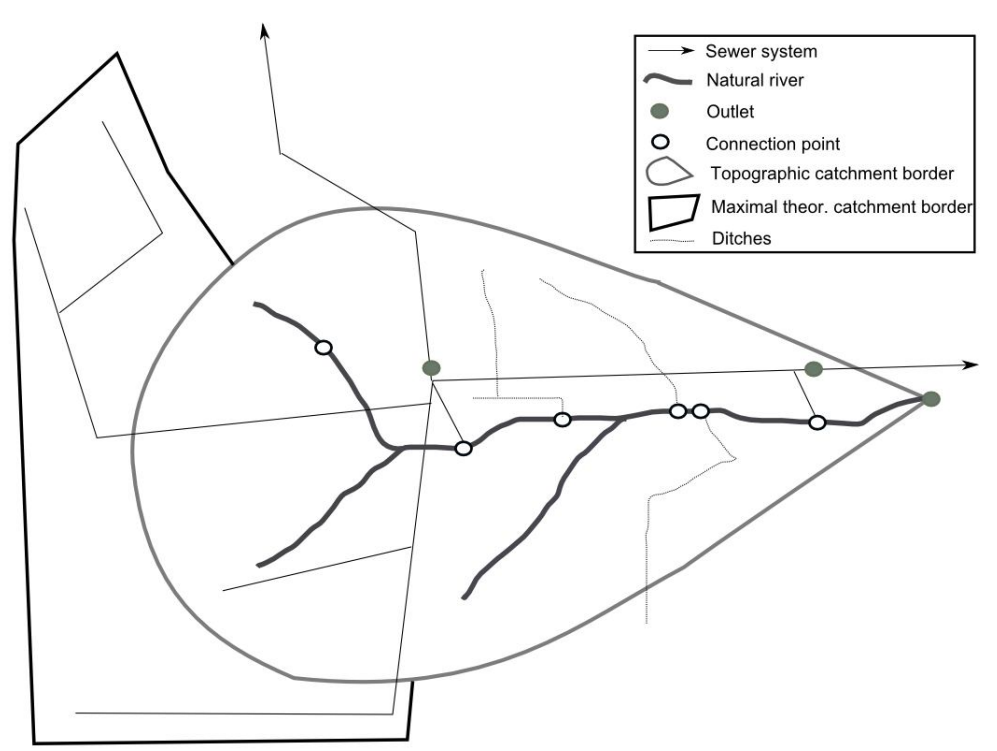

Figure 2: A virtual catchment showing the natural and the artificial drainage network composed of combined sewer system and ditches. The topographical and the maximal theoretical catchment border are indicated, as well as the measurement station at the river and two outlets of the sewer system located after connection points to the river.

\section{Determination of the drainage network.}

A further analysis of the sewer network data and the distinction between combined and separated sewer systems can give information about sewer overflow devices and possible connection points between sewer system and river network (2A), see Figure 2. The rainwater part of separated systems is often directly connected to the natural river. Therefore, special interest should be taken in areas with separated systems close to the river. All the connection points should be mapped in the field after walking along the natural river.

Not many data bases provide sufficient information about ditch and rainwater networks. The collection of this information often requires a considerable mapping effort. In order to limit the extent of the field work we propose a systematic approach for ditch mapping (2B). The ditches are only mapped in the subsequent areas of interest:

- Areas with separated systems, where only the location of the waste water pipes is known. This is due to the fact that the rain water will have to flow somewhere and will probably be drained by ditches.

- Along the road network inside the topographic catchment area, as the accumulated water on the impervious surfaces is often collected by ditches. Gravel roads and foot paths can also function as flow paths without a ditch.

- Intersections between the road network and the topographic catchment border. Often the catchment border is influenced by roads, as surface runoff tends to follow the roadditch network.

- Areas outside the topographic catchment border, connected to pumping stations or close to the neighbouring river network may contain ditches with inverse flow direction, following topography.

- In the case of an available high resolution DEM (e.g. LiDAR data), the calculated drainage network indicates gullies where channel flow is probable (Sarrazin et al., 2012). The calculated river reaches, which extend the normal river network can give information about possible stream locations.

As the ditches follow mostly artificial objects, such as roads which are visible on aerial photographs or topographical maps, they can be noted on these maps during the field work. If a higher accuracy is desired the start and end point of the ditches can be measured with a GPS. Next, retention basins have to be mapped, if they are not known from the available 
data. The final step is the construction of the drainage network out of the collected data. The drainage network will be the basis for the delineation of the subcatchments and consequently the total catchment area. Thus, the choice of the network parts, which will be connected to the natural river, should be done carefully. As we have seen in the description of drainage networks, rainwater systems are often directly connected to the natural river following topography instead of being pumped to another catchment. Therefore, we propose not to connect the rainwater part of separated sewer systems located outside the topographic catchment boundary to the studied network. Combined sewer network parts located in natural areas outside the topographic catchment are excluded from the final drainage network, because inflow to the sewer system usually happens by means of connected houses, which are non-present in natural parts. Each connection point and all retention basins should be connected to part of the artificial drainage network.

\section{Delineation of subcatchments}

The method of subcatchment and hence watershed delineation proposed here combines different approaches for urban and rural areas.

The delineation of the urban subcatchments (3A in Figure 1) follows the object oriented approach (Rodriguez et al., 2003) mentioned before. Depending on the data availability (vector data like cadastre or land use maps or aerial photographs) the delineation can be done automatically using GIS functions and scripts (Rodriguez et al., 2003) or manually based on aerial photographs and topographic maps. The principle is the same for both techniques: each cadastral unit with a building is connected to the closest drainage pipe or ditch of the derived drainage network following the principle of proximity (Rodriguez et al., 2003), illustrated in Figure 3. In case a cadastral unit is located at equal distance to two sewer pipes, the cadastral unit will be connected to the lowest sewer pipe following the principle of gravity. This results in the delineation of the urban subcatchments due to the structure of the drainage network. Each set of retention basins or sewer overflow devices is regarded as a local outlet, and the upstream area is delineated as separate subcatchment to get an estimation of the contributing area.

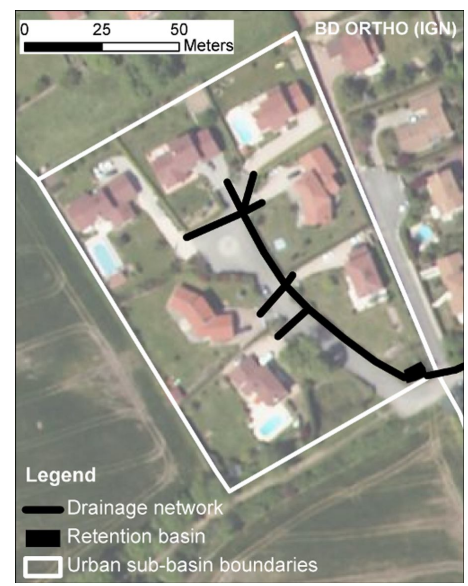

Figure 3: The aerial photography (BD ORTHO® IGN) shows urban cadastral units connected via pipes to the closest sewer system, which leads to the sub-basin delineation (white). The sub-basin is connected to a retention basin. This object-oriented sub-basin delineation does not consider the fact that part of the runoff might not be intercepted in the pipe system but drain to rural sub-basins.

The subcatchments in the rural area (3B) are delineated automatically using standard terrain analysis methods based on the $\mathrm{d} 8$ flow direction algorithm and flow direction forcing (Kenny and Matthews, 2005), as explained in the introduction, with the extended river network including the ditches. The free software Taudem (Tarboton, 2008), which is based on the 
algorithms developed by O'Callaghan and Mark (1984) and Garbrecht and Martz (1997) can be used for this task. One subcatchment is calculated for each network reach.

The rural and urban maps are merged using standard GIS software by replacing the urban part on the rural subcatchments map with the urban subcatchments. The question arises of how to treat dispersed settlements and small villages in the rural part. To account for the fact that buildings are mostly connected to the closest drainage network part, we propose to correct the outside catchment boundary in these dispersed settlements manually following the principle of proximity. This means that, in rural areas outside the topographic catchment boundary, only cadastral units next to a ditch leading inside the catchment are included in the catchment area. In contrast, built-up areas inside the topographic catchment area connected to an outside leading drainage network are excluded from the catchment area. Basic GIS coding can be used to automate the subcatchment delineation process, including the urban and rural subcatchment delineation and their merging.

\section{APPLICATION TO THE CHAUDANNE CATCHMENT}

\section{Catchment description}

The Chaudanne catchment, part of the Yzeron catchment, is an experimental catchment operated by Cemagref Lyon since 1997. Located in the suburban area south-west of Lyon, France, it was chosen to study the urban influence on hydrology and water quality (Figure 4).

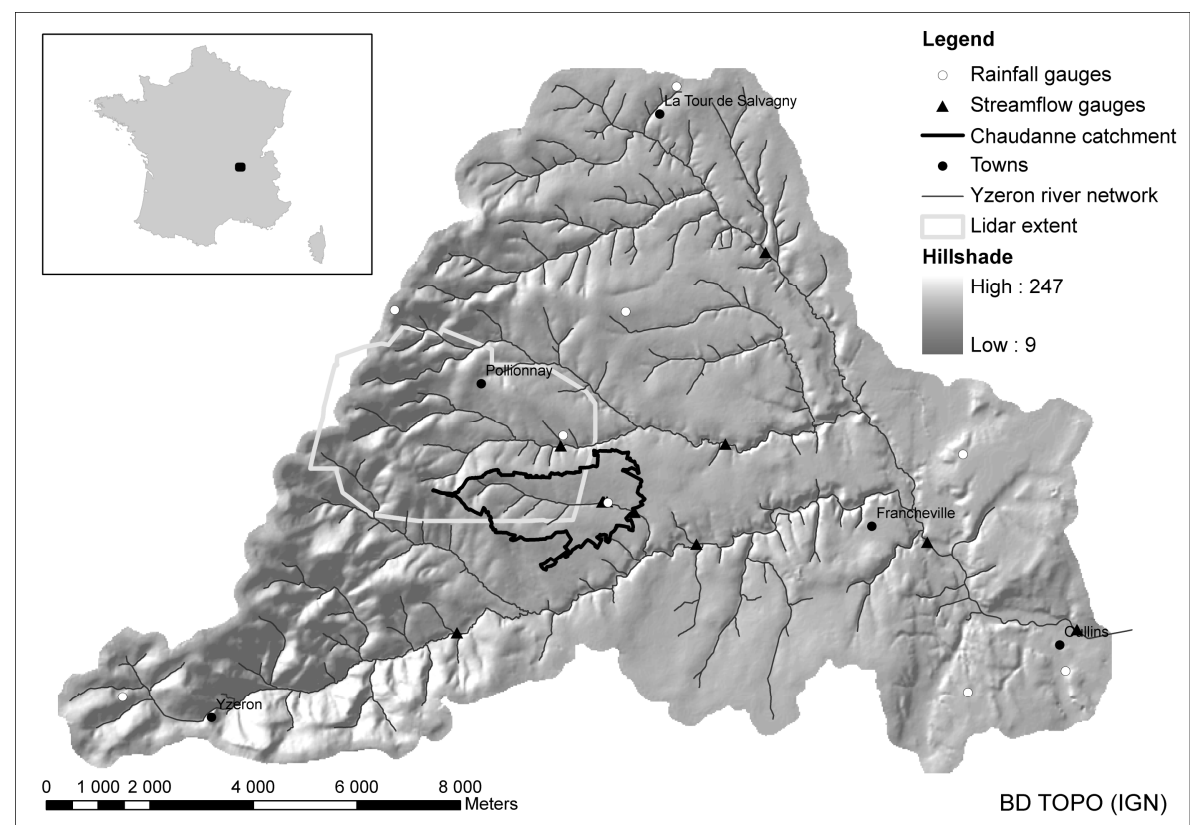

Figure 4: Location and topography of the Yzeron and Chaudanne catchment. The streamflow and rainfall gauges are indicated. The extent of the LiDAR survey is also shown. The Yzeron river network was provided by IGN.

It is one of the study sites of the Field Observatory for Urban Water Management (OTHU, 2010), which gathers eight research institutes and thirteen laboratories. It was equally chosen as a study site for the AVuPUR (Assessing the Vulnerability of Peri-Urban Rivers, Braud et al., 2010) project, to which this study contributes. The project aims at enhancing the understanding and modelling capacity of water fluxes within suburban areas. The watershed covers a surface of about $3.5 \mathrm{~km}^{2}$. Its headwater is located in a rural area and the lower part of the catchment in an urban area. The catchment geology consists of metamorphic rock of the Monts du Lyonnais series except one alluvial fan in the headwaters (BRGM, 2010) producing 
soils of silty and argillaceous sand (SIRA, 2010). The climate is temperate with alternating Continental and Mediterranean influences (Gnouma, 2006). The average annual precipitation between 1997 and 2008 was $747.9 \mathrm{~mm}$ with a standard deviation of $168.4 \mathrm{~mm}$ (Michel, 2009). The Chaudanne is an intermittent stream with a moderate discharge in winter, due to saturated zones and typically a dry period in summer, when the river can become completely dry. A sewer network, consisting of combined and separated rain water and sewer pipes, covers the lower urban part of the catchment. It is connected to a WWTP outside the catchment area. During heavy rain events, the capacity of the sewer system is exceeded, which leads to storm water overflows of mixed water towards the natural river (Lafont et al., 2006). The sewer water has to be pumped at several places. The catchment also contains several retention basins.

\section{Available data}

A DEM (BDTopo ${ }^{\circledR}$ IGN, Institut Geographic National) with a resolution of $25 \mathrm{~m}$ is available for the whole catchment area, as well as a $2 \mathrm{~m}$ resolution DEM from LiDAR data, acquired in the framework of the AVuPUR project (Braud et al., 2010, Sarrazin et al., 2012) for the northwestern part (Figure 4). The cadastre of the area is provided by CCVL (Communaute de Communes des Vallons du Lyonnais) and Grand Lyon (urban communities). A map of the Chaudanne stream and four temporary tributaries is available (BD Topo ${ }^{\circledR}$ IGN). The location of four storm water overflow outlets, the pumping station, the combined sewer system and the waste water pipes of the separated sewer system was provided by the SIAHVY (Syndicat Intercommunal d'Assainissement de la Haute Vallée de l'Yzeron, local authority in charge of sewer systems), shown in Figure 5. No digital data of the rainwater network were available in zones with separated sewer systems.

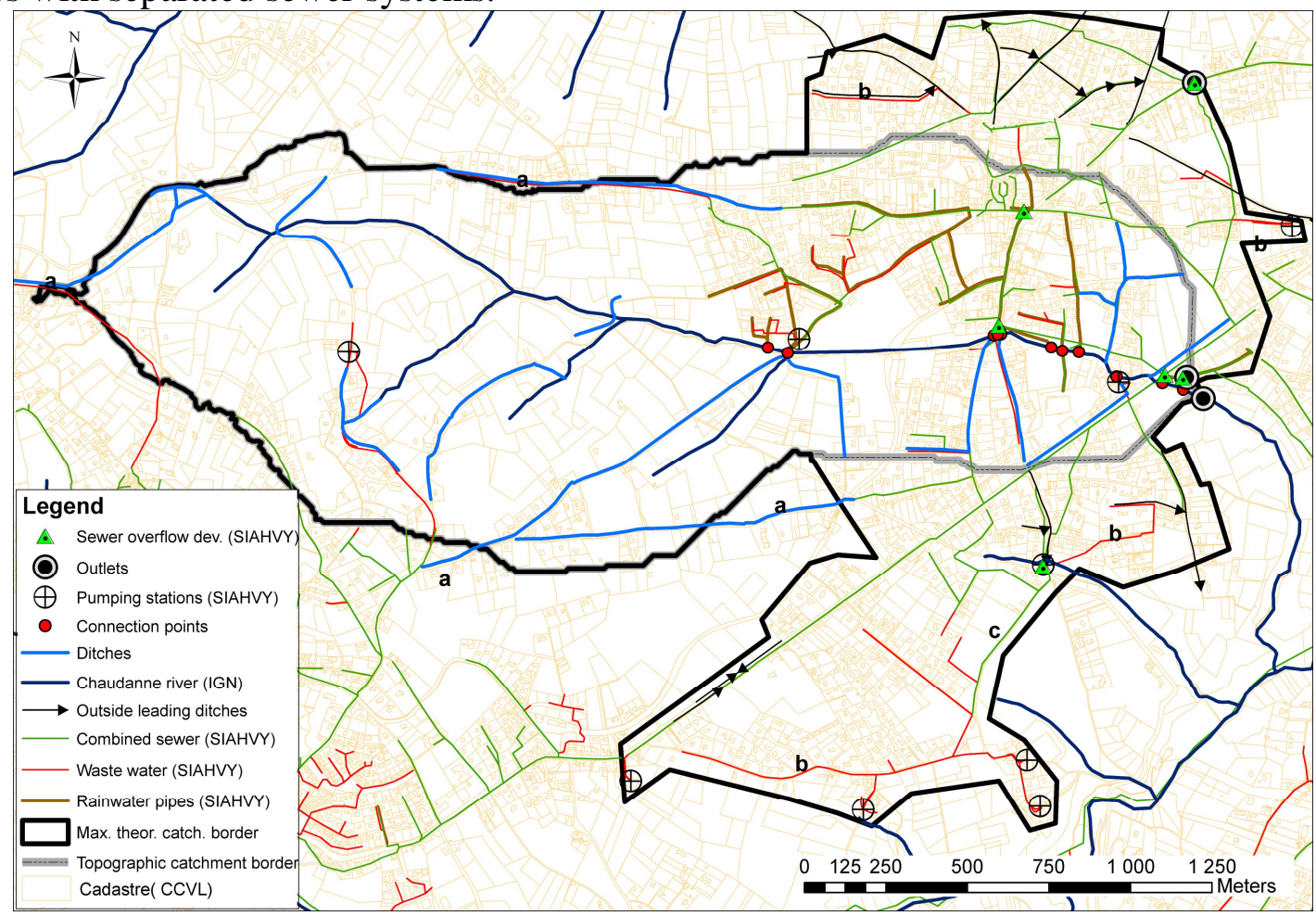

Figure 5: Topographical and maximal contributing catchment area for the Chaudanne river. The drainage network composed of the natural river $(B D$ TOPO $®$, IGN), the rainwater ditches and pipes, the combined sewer system (SIAHVY), waste water pipes (SIAHVY) and ditches flowing in the opposite direction of the sewer system are shown. Most of the ditches follow roads, as can be seen from the cadastre, provided by CCVL. The connection points with the natural river, catchment outlets, pumping stations (SIAHVY) and sewer overflow devices (SIAHVY) are indicated. a, b and c indicate areas of special interest. 


\section{Determination of drainage network}

The topographic catchment border (Figure 5) was calculated by means of the $25 \mathrm{~m} \mathrm{DEM}$ in the eastern part of the catchment and the $2 \mathrm{~m}$ LiDAR DEM in the western part. The resulting polygons were merged using standard GIS software. In addition to the natural catchment outlet, two sewer system outlets were defined: the main pipe towards the WWTP and an overflow towards another sewer system in the north-east of the catchment. For the maximal theoretical catchment border the whole sewer system is included, which leads to a $55 \%$ bigger catchment area than the topographic catchment. Eleven connection points could be mapped on the natural river from which three are combined sewer overflow devices. The other connection points are linked to rainwater pipes or ditches. It was possible to map the missing rainwater network in zones with separated sewer systems with the help of field investigations and interviews with the sewer system operator. All roads and major foot paths inside the maximal contributing area were investigated and all connected ditches were mapped graphically on a topographical map. A close examination of the intersections between roads and the topographic catchment border led to the extension of the catchment area in four locations, marked as "a" in Figure 5. In the area outside the topographic catchment several ditches with flow directions inverse to the sewer network were found (black arrows in Figure 5). Separated sewer network pipes (marked as b in Figure 5) and combined sewer network pipes in natural areas (marked as c) which were located outside the topographic catchment were excluded from the final network which is shown in Figure 7. The field work took about two days.

\section{Subcatchment delineation}

The rural subcatchments were calculated with the Taudem software (Tarboton, 2008). The delineation was conducted using flow direction forcing (Kenny and Matthews, 2005) of the extended river network, including natural, rainwater and ditch networks. Due to the integration of this network into the flow direction matrix one subcatchment is calculated for each river branch (Figure 6a), even if the river network is not in the valley floor, as is often the case for artificial ditches. The urban subcatchments were delineated manually with the help of the aerial photography by connecting the cadastral units to the closest and lowest sewer pipe (Figure 6b).

Rural and urban maps were merged by replacing the urban part of the rural map with the urban subcatchments, see Figure 7. Manual corrections were necessary in built-up zones located in rural areas outside the topographic catchment. Here, instead of the calculated area, only the cadastral units close to the ditches were connected (see "a" in Figure 7). Cadastral units inside the topographic catchment, but connected to other sewer systems were excluded (b in Figure 7).

The final map of subcatchments (Figure 7) corresponds to the maximal drained area: the subcatchments drained by the combined sewer system (dotted in Figure 7) are connected only during wet periods if a threshold discharge is exceeded. These sewer drained sub-basins are not necessarily connected at the same time. Consequently, the watershed area varies with the discharge, which has to be considered for the calculation of runoff coefficients. For the Chaudanne catchment, the dry period watershed with a surface area of $2.9 \mathrm{~km}^{2}$ expands up to $4.1 \mathrm{~km}^{2}$ during wet periods. Furthermore, in these "sewer drained" subcatchments, never $100 \%$ of runoff is connected to the natural stream as part of the water remains in the sewer towards the WWTP. The wet period watershed is $30 \%$ bigger than the topographic catchment area. Contrarily to its design, the sewer overflow devices in the Chaudanne catchment are activated nearly at each big rain event. For example, in 2007 a sewer discharge exceeding 5 $1 / \mathrm{s}$ was measured about 25 times at one of the sewer overflow devices. In addition, the map of subcatchments was classified depending on the drainage type: natural, ditch drained or urban. 

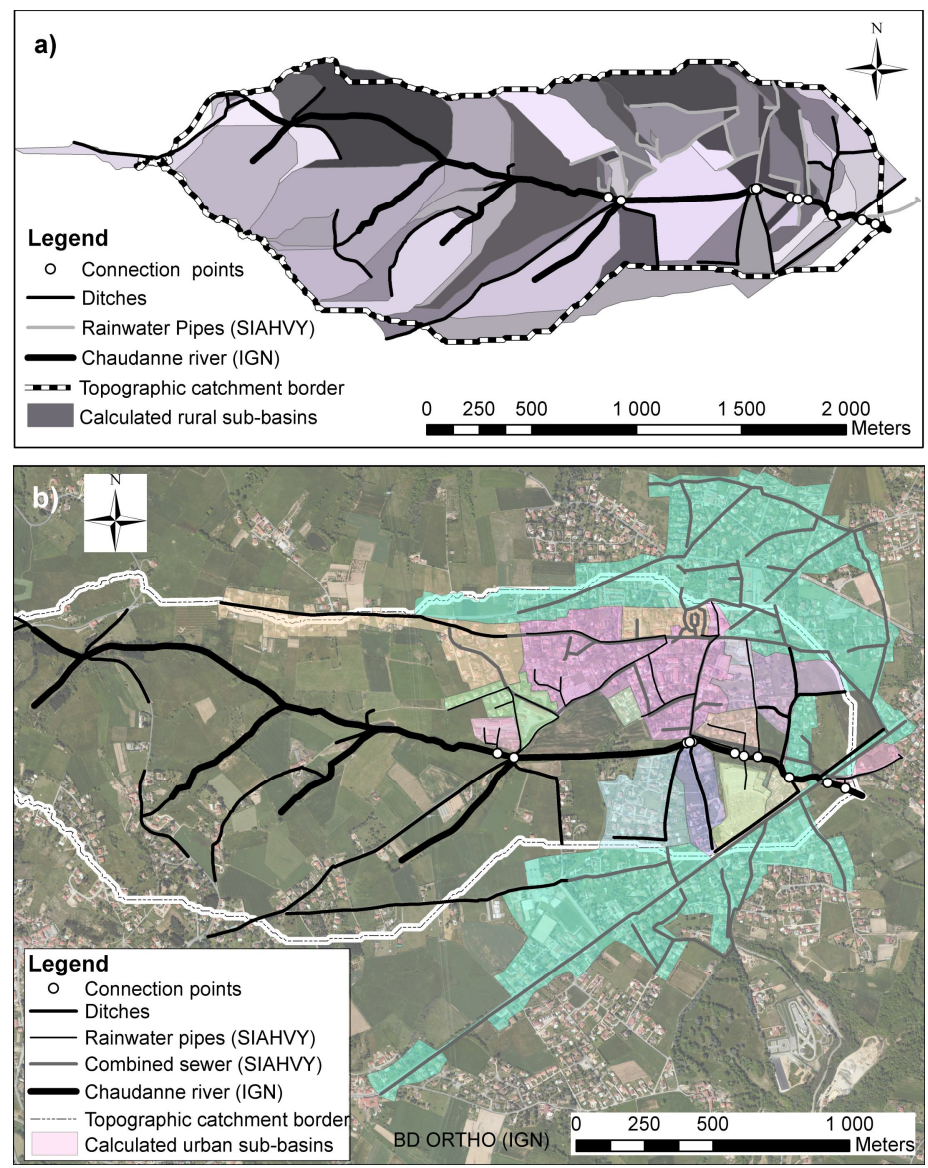

Figure 6: a) The rural subcatchments (grey scale), calculated with the $\mathrm{d8}$ algorithm and flow direction forcing and, b) the urban subcatchments (coloured) following the borders of cadastral units. The subbasins have only different colours in order to differentiate them better. The aerial photography $(B D \circledast$ Ortho) was provided by IGN.

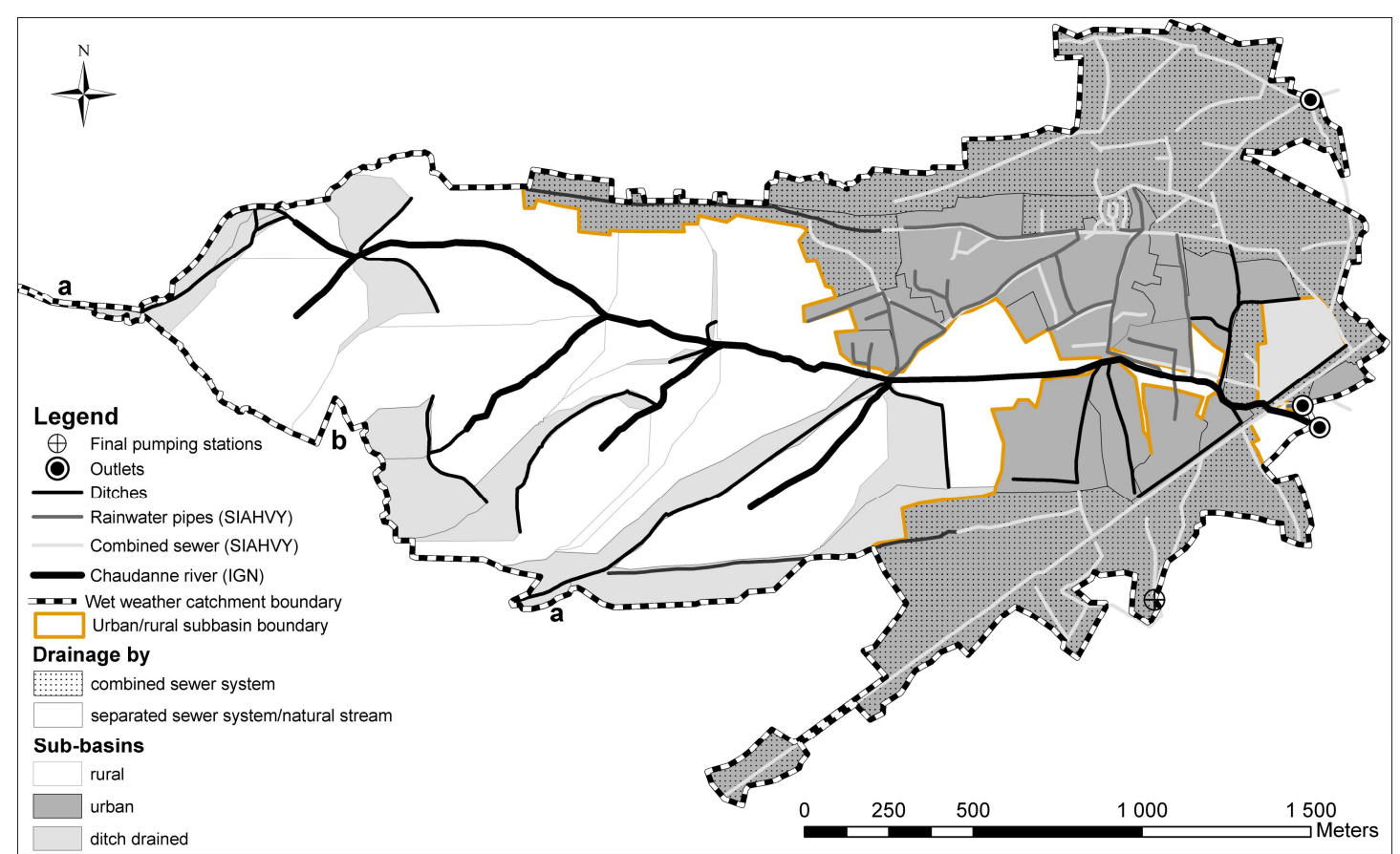

Figure 7: Final map of subcatchments. Urban subcatchments are in dark grey, rural subcatchments in white and subcatchments drained by ditches in light grey. The dotted subcatchments are only connected via stormwater overflow devices to the river. The subtraction of the dotted area from the wet catchment area results in the dry catchment area. Locations a and $b$ indicate areas of special interest. 


\section{COMPARISON OF DIFFERENT CATCHMENT DELINEATION METHODS}

\section{Description of methods}

In order to evaluate the benefit of the field work, the presented method for subcatchment delineation and network determination, here referred to as Method 1, was compared to six other methods (listed in Table 1), which were only based on digital data. As input for these methods we used the combined sewer system (CSS), the natural stream network (NSN), the road network and a new $5 \mathrm{~m}$ DEM interpolated from the available $25 \mathrm{~m}$ DEM (DEM25-5).

Method 2 consists of flow direction forcing with the combined sewer network and the natural river network using the Taudem software (Tarboton, 2008) as explained for Method 1. Hence, the flow direction matrix based on the original DEM is modified in order to integrate the flow directions of the drainage network. Then, the subcatchments are determined based on this flow direction matrix.

Table 1: Catchment delineation methods used in this study and the corresponding input data. DEM25-5 and DEM2 are the digital elevation model with a resolution of 25 and $2 \mathrm{~m}$, CSS the combined sewer system and NSN the natural stream network.

\begin{tabular}{|l|l|l|}
\hline ID & Method & Input data \\
\hline 1 & $\begin{array}{l}\text { Proposed method with field } \\
\text { observations } \\
\text { Rural: flow direction forcing } \\
\text { Urban: Object oriented approach }\end{array}$ & $\begin{array}{l}\text { DEM25-5, LiDAR DEM2, CSS, NSN, } \\
\text { aerial photography, field observations } \\
\text { (ditches, rainwater pipes) }\end{array}$ \\
\hline 2 & $\begin{array}{l}\text { Flow direction forcing with CSS and } \\
\text { NSN }\end{array}$ & DEM25-5, CSS, NSN \\
\hline 3 & $\begin{array}{l}\text { Calculation of sub-basins for points / } \\
\text { ArcGIS Watershed tool + topgraphic } \\
\text { catchment boundary }\end{array}$ & $\begin{array}{l}\text { DEM25-5, sewer inlet points as vector } \\
\text { data }\end{array}$ \\
\hline $4 \mathrm{a}$ & $\begin{array}{l}\text { Stream burning of road with variable } \\
\text { depth }(\text { Gironas et al., 2010) }\end{array}$ & $\begin{array}{l}\text { DEM25-5, road vector data with altitudes } \\
\text { of start and end point }\end{array}$ \\
\hline $4 \mathrm{~b}$ & $\begin{array}{l}4 \mathrm{a}+\text { Stream burning of CSS and NSN: } \\
1 \mathrm{~m} \text { depth }\end{array}$ & DEM resulting from 4a, CSS and NSN \\
\hline $4 \mathrm{c}$ & $\begin{array}{l}4 \mathrm{a}+\text { Stream burning of CSS and NSN: } \\
5 \mathrm{~m} \text { depth }\end{array}$ & Same as 4b \\
\hline $4 \mathrm{~d}$ & $\begin{array}{l}4 \mathrm{a}+\text { Stream burning of CSS and NSN: } \\
10 \mathrm{~m} \text { depth }\end{array}$ & Same as 4b \\
\hline
\end{tabular}

In Method 3 contributing areas were calculated from the original DEM25-5 for each sewer inlet point by means of the ArcGIS SpatialAnalyst/Hydrology/Watershed tool. The distinctive feature of Method 3 is the calculation of subcatchments for points instead of lines. As the calculated subcatchments of Method 3 correspond only to the catchment area of the sewer system, the surface was merged with the topographic catchment boundary of Method 1 . This topographic catchment border was chosen for the catchment area of the natural stream, as it is the most currently used catchment border in catchment delineation processes and it is not particularly specific to Method 1. Like in Method 2, in Method 3 the network length corresponds to the length of the natural stream and the combined sewer system.

Several variants of stream burning were tested in Method 4. Burned objects were the natural stream network, streets, the combined sewer system and buildings. The addition of buildings $5 \mathrm{~m}$ in size or greater was tested and found to only have a minor influence on flow paths and catchment area. Therefore, the results are not shown here. An attempt was made to apply the variable road and sewer system burning proposed by Gironas et al. (2010). However, only the 
variable road burning could be applied successfully because of missing sewer pipe depth data. The BD TOPO (IGN) provided the altitude data for the roads. This method will be referred to as Method 4a (see Table 1). Constant burning of roads with different depths $(0.5 \mathrm{~m}, 1 \mathrm{~m}, 5 \mathrm{~m}$, $10 \mathrm{~m}, 20 \mathrm{~m}$ ) was equally tested, but will not be shown here, as the variable burning gave more realistic results. In order to compensate for the altitude data of the sewer pipes different burn depths ( $1 \mathrm{~m}$ for Method $4 \mathrm{~b}, 5 \mathrm{~m}$ for Method $4 \mathrm{c}$ and $10 \mathrm{~m}$ for Method $4 \mathrm{~d}$ ) of the combined sewer system and natural river network were tested based on the DEM resulting from the variable road burning (4a). The subcatchments and river networks were calculated for the modified DEMs (4a-d) using the Taudem software without the flow direction forcing option. As the drainage networks of Methods 4a to $4 \mathrm{~d}$ arise from raster maps, the Douglas and Peucker (1973) algorithm for line simplification with $5 \mathrm{~m}$ threshold was applied. Without this correction, the network length is not representative because the raster based network would be longer than the normal, rather straight, network.

\section{Description of validation criteria}

Several criteria of watershed area and drainage network produced by each method were chosen to evaluate the different methods. Method 1 is regarded as the reference, as it is based on additional field information. The criteria are presented in the following list:

i) Watershed area: total calculated watershed area.

ii) Overlapping surface: results from intersection of the concerned watershed area with the area of Method 1. This criterion shows the capability of the methods to represent the same watershed area.

iii) Excessive surface: arises from subtraction of the overlapping surface from the watershed area of Method 1. It shows the overestimated surface.

iv) Surface drained by sewer system: sum of all subcatchments drained by the combined sewer network. Often this surface is the basis for the sizing of sewer pipes.

v) Network length: The length of the calculated network.

vi) Total network agreement: The length of the calculated network of a given method that lies within a zone defined by a buffer of 10 meters around the total network consisting of combined sewer system, rainwater network and the natural stream is compared to the length of this total network (Figure 8).

vii) Combined and natural agreement: the length of the calculated network of a given method that lies within a zone defined by a buffer of 10 meters around the network consisting of combined sewer system and the natural river is compared to the length of this network.

viii) Excessive network: consists of the difference of the total network length and the total network agreement of a given method in $\mathrm{km}$, compared to its total network length. It defines erroneously detected network parts.

ix) Detected ditches: The network length detected in a buffer of 10 meters around the ditches is compared to the total ditch length. It shows the capability of representing the artificial ditches without field work.

\section{Results of comparison}

Table 2 shows the calculated criteria for all of the methods. The maps of the subcatchments and drainage networks are presented in Figure 9. Inset 3 of Figure 9 shows the calculation of contributing areas for inlet points in Method 3, which results in a discontinuous catchment area with many small subcatchments. All the other watersheds have continuous surfaces. Methods 2, 4c and 4d have the largest watershed areas and overlap to 98 and 96\% (4c and d) the reference watershed, respectively. However, they overestimate the catchment by 12 to 
$15 \%$. This occurs mainly in the southern part outside the topographic catchment border, where natural and artificial flow paths intersect (an enlargement of this region is shown in Figure $10)$.

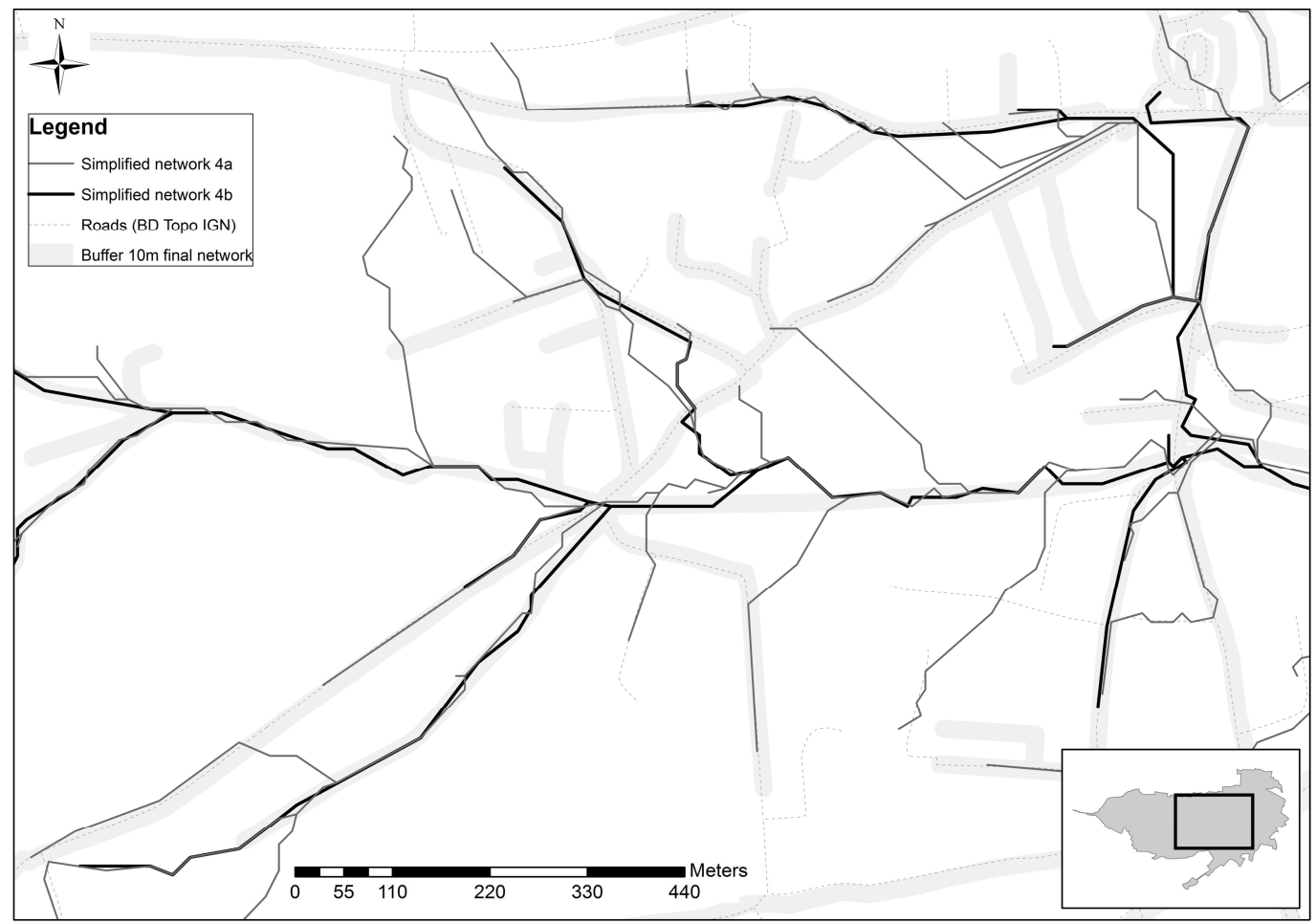

Figure 8: Visualization of the network agreement criterion, which represents the network length falling inside a buffer of 10 meters around the total network (i.e. combined sewer system, rainwater network and the natural stream). Drainage networks of Methods 4a (only based on the road network) and 4b (using road, combined sewer system and natural stream) are compared to this buffer and the road network. Method $4 \mathrm{~b}$ reduces the network density and enhances thus the agreement with the real network (buffer), but detects less roadside ditches or pipes.

Table 2: The results for the different criteria and methods. Method 1 is the proposed method, Method 2 uses flow direction forcing, Method 3 contains subcatchments for inlet points and Methods 4a -d use different kind of stream burning: (a) uses just variable road burning; (b), (c) and (d) use variable road burning and the burning of the drainage network of 1,5 and $10 \mathrm{~m}$, respectively.

\begin{tabular}{|l|l|l|l|l|l|l|l|l|}
\hline Criteria/Method & Unit & Method 1 & Method 2 & Method 3 & Method 4 & & & \\
\hline Watershed area & $\mathrm{km}^{2}$ & 4.10 & 4.55 & 3.516 & 3.095 & 3.10 & 4.28 & 4.28 \\
\hline $\begin{array}{l}\text { Overlapping } \\
\text { surface }\end{array}$ & $\%$ & 100 & 97.88 & 89.91 & 85.35 & 85.43 & 96.21 & 96.20 \\
\hline Excessive surface & $\%$ & 0.0 & 15.10 & 04.02 & 0.99 & 0.99 & 11.58 & 11.58 \\
\hline $\begin{array}{l}\text { Surface drained } \\
\text { by sewer system }\end{array}$ & $\mathrm{km}^{2}$ & 1.22 & 2.20 & 0.66 & 0.0 & 0.68 & 1.97 & 2.0 \\
\hline Network length & $\mathrm{km}$ & 32.19 & 22.38 & 22.38 & 21.23 & 9.65 & 11.03 & 37.85 \\
\hline $\begin{array}{l}\text { Total network } \\
\text { agreement }\end{array}$ & $\%$ & 100 & 68.52 & 68.52 & 30.41 & 24.15 & 33.64 & 70.95 \\
\hline $\begin{array}{l}\text { Combined and } \\
\text { natural } \\
\text { agreement }\end{array}$ & $\%$ & 100 & 100 & 100 & 31.32 & 33.59 & 48.95 & 89.82 \\
\hline Excessive network & $\%$ & 0 & & & & & & \\
\hline Detected ditches & $\%$ & 100 & 0.38 & 0.38 & 53.38 & 18.58 & 0.76 & 39.01 \\
\hline
\end{tabular}



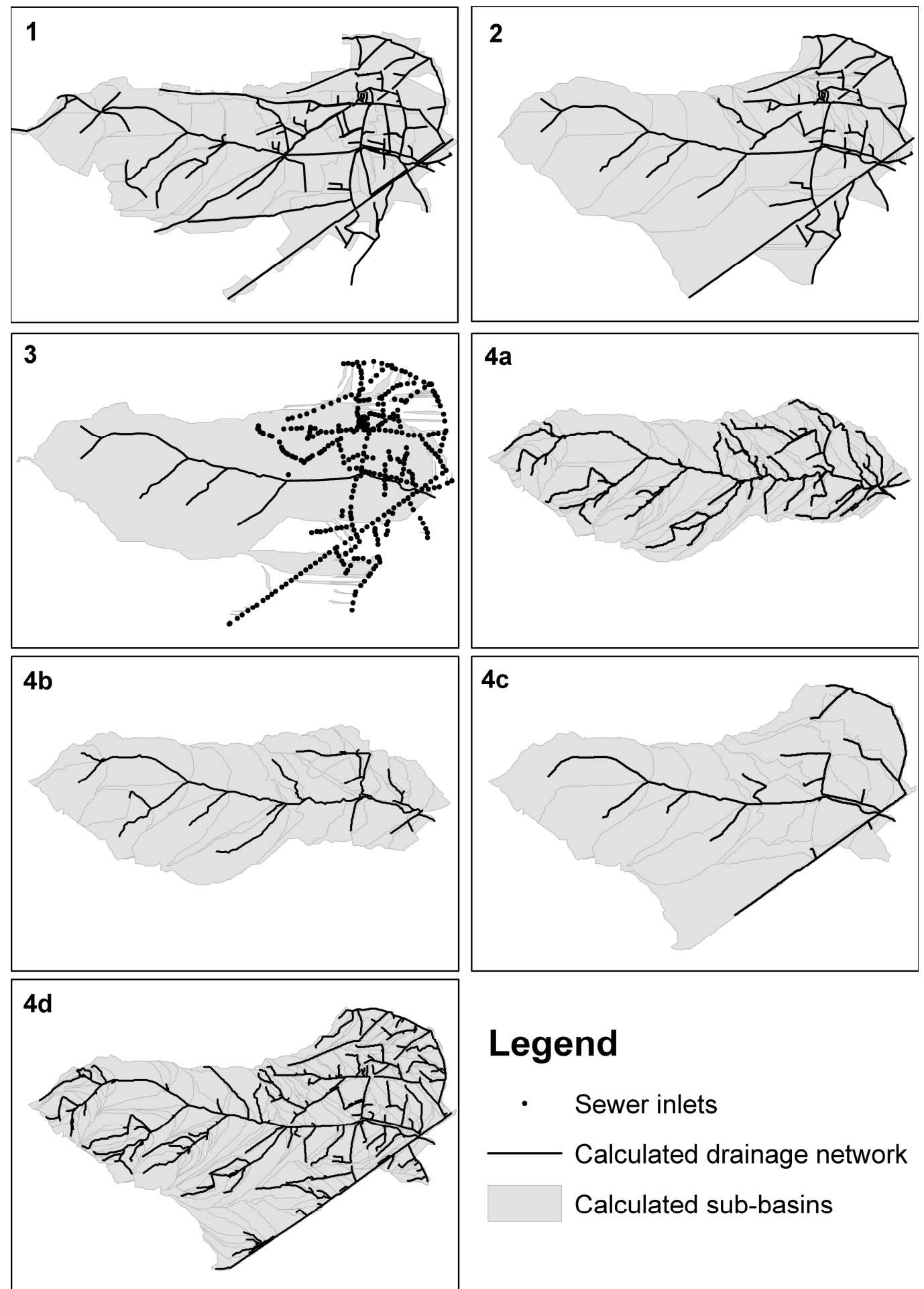

\section{Legend}

- Sewer inlets

Calculated drainage network

Calculated sub-basins

Figure 9: Subcatchment maps and calculated drainage networks for Methods 1, 2, 3, 4a-d. Polygons correspond to calculated sub-basins, lines represent the calculated drainage networks and the points (panel 3) are the sewer inlets, which were used for the calculation of the corresponding sub-basins.

In Method 1 surface runoff in natural areas drains towards the natural streams $(\mathrm{a}, \mathrm{b}$ and $\mathrm{c}$ in Figure 10), which are tributaries of the Yzeron river and not the Chaudanne stream. Consequently, the natural areas in Figure 10 are excluded from the Chaudanne catchment as far as surface runoff is considered. Methods 2 and $4 \mathrm{c}$ do not make the difference between urban and natural areas and include thus these surfaces into the target watershed, which leads to a wrong representation of the surface flow paths. However, uncertainty remains in pumped areas (c in Figure 10), where ditches and combined sewers flow in opposite direction. Part of 
the surface runoff is probably drained by the ditches towards the natural stream leading outside the Chaudanne catchment, and the other part is drained by the combined sewer system. Only Methods 1 and 2 included this pumped area to the watershed.

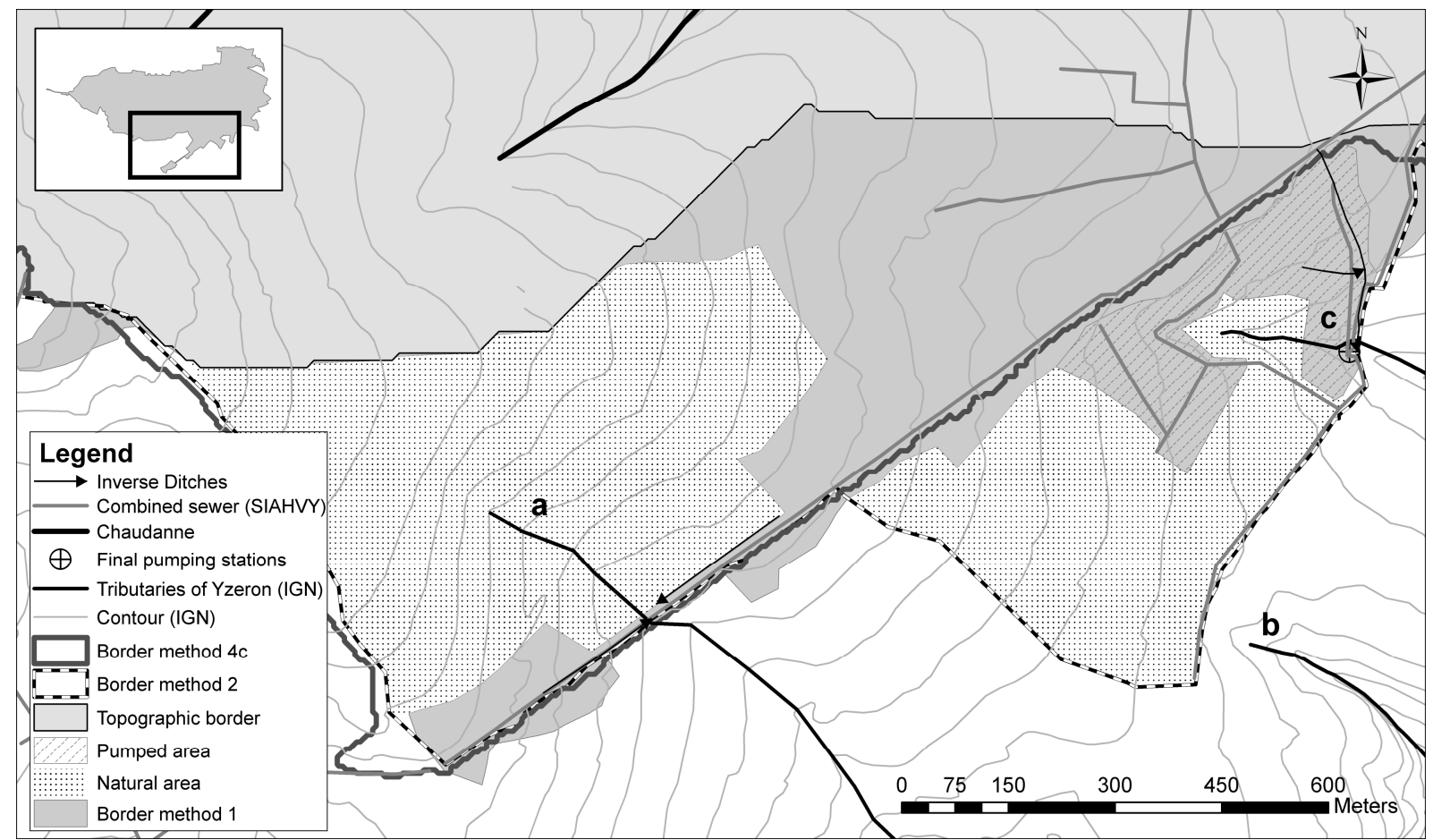

Figure 10: Enlargement of the southern part of the catchment showing a comparison of the watershed limits using Methods 1, 2, 4c and the topographic catchment border. Field observations showed that the surface runoff in the natural areas (dotted) flows to tributaries of the Yzeron $(a, b, c)$, which are not connected to the Chaudanne stream, whereas the urban areas are drained by the combined sewer system. Only the object oriented Method 1 makes a difference between urban and natural areas and excludes the areas drained by the tributaries of the Yzeron.

The comparison of Methods 4b, c and d (refer to Figure 9) show the importance of the burn depth parameter on the catchment delineation. There seems to be a certain threshold burn depth (between 1 and $5 \mathrm{~m}$ ), which is necessary to connect areas outside the topographic catchment border against the slope direction to the study catchment.

None of the automatic methods correctly represent the surface drained by the sewer system. Methods 3, 4a and b underestimate the surface by at least $44 \%$, whereas Methods 2, 4c and d overestimate it by $60 \%$.

As can be seen in Figure 9, the longest network length can be found with Method 4d, caused by the stream burning depth of $10 \mathrm{~m}$. The complete network is best represented by Methods 2 , 3 and $4 \mathrm{~d}$, which is shown by the total network agreement. However, looking at the excessive network criterion, we can see that nearly $40 \%$ of Method $4 d$ 's network does not correspond to any network observed in the field. Consequently, Methods 2 and 3, which are also the only methods capable of reproducing $100 \%$ of their input network, lead to a more realistic result. Nevertheless, these two methods cannot detect artificial ditches. These could only be detected with Methods 4a and 4d. Figure 8 shows an extract of the urban part of the watershed. The drainage networks of Method $4 \mathrm{a}$ and $4 \mathrm{~b}$ are compared to the road network and the buffer around the drainage network of Method 1. We can see that the introduction of the sewer system stream burning reduces the network density, but enhances the agreement with the real network represented by the buffer. Nonetheless, the agreement with the road network decreases. 


\section{DISCUSSION}

The proposed method is as general as possible. However, differences in suburban catchment characteristics caused by differences in climate, geology and population as well as differences in available data will mean that the method might have to be adapted when applied to other catchments.

As we have seen, drainage patterns in suburban areas can be quite complex. In case sewer systems were not mapped during installation, the detection of their location and connections during field surveys can be difficult. Many ditches are also piped in some parts and the determination of flow directions and links to other pipes, especially on road cross-sections or roundabouts, can require tracer investigations. This involves time consuming field investigations.

The calculation of the rural subcatchments is based on the DEM and thus its resolution plays an important role. In our case, we had the LiDAR DEM with $2 \mathrm{~m}$ resolution only for part of the rural catchment area and a DEM with a resolution of $25 \mathrm{~m}$ for the rest of the catchment. It would be interesting to see the results based on a LiDAR DEM for the whole catchment area, especially for the urban part.

Concerning the delineation of the urban subcatchments only the manual method based on aerial pictures was shown. This method allows the determination of subcatchments in a more general manner. The automatic method will strictly connect only plots of land classified as urban cadastral units leading to a spotted subcatchment map. Hence, the automatic method depends even more on the input data, such as classification of land use units. No parallel sewer systems are permitted in the automatic method. This means that the results of the automatic and manual methods will not necessarily be the same, which can have an impact on the calculation of runoff coefficients (here defined as ratio of cumulative discharge/rainfall for a certain interval of time).

Concerning the object oriented approach, the question arises as to whether or not it is correct to consider an administrational cadastral unit as hydrological unit. Does the water in the yard really flow to the same place as the building, which is connected via underground pipes (Rodriguez et al. 2008)? The answer might lie between the object oriented and the topographical approach. And there is also uncertainty in the drainage network to which a building is actually connected when there are several close by.

The comparison with the digital data based methods showed that none of them were capable of capturing all the field observations. Either the catchment area was too small, as for methods $3,4 \mathrm{a}$ and $4 \mathrm{~b}$, or too big as for methods $2,4 \mathrm{c}$, and $4 \mathrm{~d}$.

Due to the continuous development of suburban areas, a wide variety of drainage networks can be found in these areas. It is difficult to reproduce these drainage networks, as they consist of different sources, such as the sewer system, the natural stream and ditches. By means of the variable road burning, part of the ditches can be detected, but without verification in the field, they cannot be distinguished from the erroneous detected flow paths. The methods of comparison are mainly based on topography, except Method 3, which makes it complicated to represent cross-flow patterns, different flow directions of the drainage network and parallel networks. By calculating subcatchments for each inlet point, as used in most storm water models, the drainage network is independent of the topography and crossflow patterns can be reproduced. However, this results in many miniscule subcatchments, and the continuity of the flow along ditches is no longer represented. Only with Methods 2 and 3 it was possible to obtain the complete input network, and thus include the pumped area.

The catchment delineation in Method 1 is based on both surface and pipe flow paths. For regions outside the topographic catchment area, the consideration of subsurface flow and drainage by sewer pipes has an influence on the catchment boundaries. Thus, the subsurface catchment boundary would correspond to the boundary of Method 2, as sewer pipes in both 
natural and urban parts intercept the subsurface flow (Figure 10). In areas outside the topographic catchment border, surface and subsurface catchment borders can thus differ.

The process times of the individual methods vary significantly. The flow direction forcing and constant stream burning is relatively straightforward, as the necessary GIS algorithms can be automated using standard GIS functions provided by most available software. In contrast, the preparation of the data for the variable stream burning revealed to be quite tedious. In addition, elevation data for sewer pipes are typically not available. The time spent in the field for Method 1 was only about two days. The treatment of the field data and calculation of subcatchments took about one week. However, cost of fieldtrips might be relevant, particularly when the basin is in a location not easy to access. Once all field information is gathered, most steps of Method 1 can be done automatically.

These results show the importance of field investigations and the difficulty to capture all observed suburban drainage characteristics with one method. Thus, a combination of different approaches as in Method 1 provides better representation of the urban and natural features of suburban areas. It enables the capturing of all of the networks with cross-flow patterns, sewer overflow devices with split flow patterns, parallel drainage networks and pumped areas.

\section{CONCLUSIONS}

Slowly growing suburban areas often have complex drainage systems, consisting of a combination of ditches, sewer systems, sewer overflow devices, pumping stations and retention basins. The knowledge and accurate representation of the drainage system and contributing watershed area are important for storm water management, water quality questions, calculation of hydrological criteria as runoff coefficients and hydrological modelling.

This paper specifies a systematic approach to collect the information required for the delineation of suburban watersheds and to build the necessary database. It proposes then a semi-automated approach for the derivation of drainage areas based on minimal manual manipulation. This semi-automated approach is then compared to other documented automated approaches.

The comparison points out that the current purely automatic methods for catchment delineation and calculation of drainage systems based on DEMs are not able to correctly represent the suburban terrain. Unfortunately the relevance of field observations is many times disregarded when automatic methods and digital information are available. This study showed that a time efficient field survey (without topographical survey, but only mapping based on cadastral maps) can considerably improve the catchment delineation. Contact with local authorities is also recommended as they can provide further data and information about intended building projects and modifications of the sewer system.

Once the field data are collected, the combination of the object oriented approach and the flow direction forcing allowed us to represent relatively well both the urban and the rural zones. Most catchment delineation steps of this combined method can be done automatically, as shown by Jankowfsky (2011). Further research and developments would probably allow the automatization of the remaining manual steps, such as the corrections of built-up areas outside the topographic catchment area. A larger catchment composed of several subcatchments (each of these subcatchments being the size of the Chaudanne) would probably be more suitable for this purpose.

This study shows the significance of dry and wet period watershed variability, which is often not considered. Taking a constant watershed area instead of a variable one can introduce errors, e.g. when calculating runoff coefficients. Furthermore, the wet period watershed area is relevant for the activation of sewer overflow devices. In the Chaudanne catchment, the 
SODs are activated at nearly each big rain event contrarily to its design, which has negative effects on the water quality.

The distinction in urban, natural and ditch-drained subcatchments can give information about the response time, as urban subcatchments with a higher impermeable fraction will respond faster than natural subcatchments. Because of the road runoff, ditch drained subcatchments have a quicker response time than natural subcatchments. The resulting subcatchment map is also interesting for water quality issues. The contamination risk in urban and ditch drained subcatchments is higher than in natural subcatchments. If a natural subcatchment is located downstream of an urban subcatchment the water quality might improve due to dilution. The resulting subcatchment map can be directly used for storm water management questions and hydrological modelling. The hydrological model PUMMA (Peri-Urban Model for landscape MAnagement) was designed based on the drainage network and subcatchments determined in this article (Jankowfsky et al., 2011; Jankowfsky, 2011).

To further reduce the uncertainties still incorporated in the map, it would be interesting to perform some tracer investigations at points of interest. Also, the gathering of data about road cross-sections would permit the application of the approach described by Duke et al. (2003, 2006) and thus allow the determination of hydrologically unconnected areas.

It would be interesting to validate the subcatchment map by means of detailed discharge data from subcatchment outlets. This would also allow the estimation of flow threshold values for the sewer overflow devices, and it would permit the determination of the flow threshold which defines the limit between dry and wet period catchment area.

\section{ACKNOWLEDGEMENTS}

The study was funded by the by the French Agence Nationale de la Recherche (ANR) under contract $n^{\circ}$ ANR-07-VULN-01. CCVL, IGN, Grand Lyon, SAGYRC, SIAVHY, Sol-Info Rhône-Alpes provided data used in the study. Finally, the Chilean FONDECYT program provided partial support through Grant No. 11090136.

\section{REFERENCES}

Augusto CVG, Bonnet MP, Filho OCR, Mansur WJ. 2009. Improving hydrological information acquisition from DEM processing in floodplains. Hydrological Processes 23: 502-514.

BRGM, 2010. Bureau de recherches géologiques et minières. http://infoterre.brgm.fr/viewer/MainTileForward.do;jsessionid=C6247604415C79ABC47269 563FD5969E. Consulted on 2010/09/21.

Bocher E. 2005. Impacts des activités humaines sur le parcours des écoulements de surface dans un bassin versant bocager : essai de modélisation spatiale. Application au Bassin versant du Jaudy-Guindy-Bizien (22). Thèse de l'Université de Rennes, 337 p.

Bocher E, Martin JY. 2009. TANATO2: TIN-based approach to evaluate impact of natural and anthropogenic artefacts. Abstracts Proceedings of the International Opensource Geospatial Research Symposium OGRS 2009, Nantes, France, 8-10 July 2009: 56-59.

Braud I, Chancibault K, Debionne S, Lipeme Kouyi G, Sarrazin B, Jacqueminet C, Andrieu H, Béal D, Bocher E, Boutaghane H, Branger F, Breil P, Chocat B, Comby J, Dehotin J, Dramais G, Furusho C, Gagnage M, Gonzalez-Sosa E, Grosprêtre L, Honegger A, 
Jankowfsky S, Joliveau T, Kermadi S, Lagouy M, Leblois E, Martin JY, Mazagol PO, Michell K, Molines N, Mosini ML, Puech C, Renard F, Rodriguez F, Schmitt L, Thollet F, Viallet P. 2010. The AVuPUR project (Assessing the Vulnerabiliy of Peri-Urban Rivers) : experimental set up, modelling strategy and first results. Proceedings of the $7^{\text {th }}$ Novatech 2010 Conference, June 28-July 1 2010, Lyon, France, 10pp.

Callow JN, Niel KPV, Boggs GS. 2007. How does modifying a DEM to reflect known hydrology affect subsequent terrain analysis? Journal of Hydrology 332: 30-39. DOI: 10.1016/j.jhydrol.2006.06.020.

Carluer N, Marsily GD. 2004. Assessment and modelling of the influence of man-made networks on the hydrology of a small watershed: implications for fast flow components, water quality and landscape management. Journal of Hydrology 285: 76-95.

Choi JY, Engel BA. 2003. Real-Time Watershed Delineation System Using Web-GIS. Journal of computing in civil engineering 17(3): 189-196. DOI:10.1061/(ASCE)08873801(2003)17:3(189).

Choi JY, Engel BA, Theller L, Harbor J. 2005. Utilizing web-based GIS and SDSS for hydrological land use change impact assessment. Transactions of the ASAE 48(2): 815-822.

Costa-Cabral MC, Burges SJ. 1994. Digital elevation model networks (DEMON): a model of flow over hillslopes for computation of contributing and dispersal areas. Water Resources Research 30: 1681-1692.

Denver Council of Governments. 1969. Anon., 1969. Urban Storm Drainage Criteria Manual, Wright-McLaughlin Engineers 1969.

Djokic D, Maidment DR. 1991. Terrain analysis for urban stormwater modelling. Hydrological Processes 5(1): 115-124.

Djordjevic S, Prodanovic D, Maksimiovic C. 1999. An approach to simulation of dual drainage. Water Science and Technology 39 (9): 95-103.

Doan JH. 2000. Hydrologic model of the Buffalo Bayou using GIS. Hydrologic and hydraulic modelling support with geographic information systems, DR Maidment and D Djokic (eds). ESRI, Redlands, Calif., 113-143.

Douglas I. 2006. Peri-urban ecosystems and societies transitional zones and contrasting values. In Peri-Urban Interface: Approaches to Sustainable Natural and Human Resource Use, edited by D. McGregor, D. Simon, D. Thompson, pp. 18-29. London, UK: Earthscan Publications Ltd.

Douglas DH, Peucker TK. 1973. Algorithms for the Reduction of the Number of Points Required to Represent a Digitized Line or Its Caricature. Canadian Cartographer 10(2):112122. DOI: 10.3138/FM57-6770-U75U-7727.

Duke GD, Kienzle SW, Johnson DL, Byrne JM. 2003. Improving overland flow routing by incorporating ancillary road data into Digital Elevation Models. Journal of Spatial Hydrology 3(2): 1-27. 
Duke GD, Kienzle SW, Johnson DL, Byrne JM. 2006. Incorporating ancillary data to refine anthropogenically modified overland flow paths. Hydrological Processes 20: 1827-1843.

Elgy J, Maksimovic C, Prodanovic D. 1993. Matching standard GIS packages with urban storm drainage simulation software. Proceedings of Vienna Conference-HydroGIS 93: Applications of Geographic Information Systems in Hydrology and Water Resources, Vol. 211, IAHS, Wallingford, UK, 151-160.

Fried JS, Brown DG, Zweifler MO, Gold MA. 2000. Mapping Contributing Areas for Stormwater Discharge to Streams Using Terrain Analysis. In: Terrain Analysis: Principles and Applications. Wilson JP, Gallant JC (eds). John Wiley \& Sons, New York, ISBN 0-47132188-5, 183-203.

Garbrecht J, Martz LW. 1997. The assignment of drainage direction over flat surfaces in raster digital elevation models. Journal of Hydrology 193: 204-213.

Gironas J, Niemann JD, Roesner LA, Rodriguez F, Andrieu H. 2010. Evaluation of methods for representing urban terrain in storm-water modelling. Journal of hydrologic engineering 15(1): 1-14.

Gnouma R. 2006. Aide à la calibration d'un modèle hydrologique distribué au moyen d'une analyse des processus hydrologiques : application au bassin versant de l'Yzeron. Thèse de l'institut national des sciences appliquées de Lyon. 263 pp.

Graf WL. 1977. Network characteristics in suburbanizing streams. Water Resources Research 13(2): 459-463.

Greene RG, Cruise JF. 1995. Urban watershed modelling using geographic information system. Journal of Water Resources Planning and Management 121(4): 318-325.

Hammond M, Han D. 2006. Issues of digital maps for catchment delineation. Proceedings of the Institution of Civil Engineers. Water Management 159. 45-51.

Hellweger FL. 1997. AGREE - DEM Surface Reconditioning System, http://www.ce.utexas.edu/prof/maidment/gishydro/ferdi/research/agree/agree.html consulted on $15 / 10 / 2010$.

Hutchinson MF. 1989. A new procedure for gridding elevation and stream line data with automatic removal of spurious pits. Journal of Hydrology 106: 211-232.

Jankowsky S, Branger F, Braud I, Rodriguez F, Debionne S, Viallet P. 2011. Influence of urban expansion on the hydrology of small catchments: development of the suburban PUMMA model by coupling of urban and rural hydrological models. Proceedings of the $12^{\text {th }}$ International Conference on Urban Drainage, ICUD 2011, 11-16 September 2011, Porto Alegre, Brazil.

Jankowfsky S. 2011. Understanding and modelling of hydrological processes in small periurban catchments using an object oriented and modular distributed approach. Application to 
the Chaudanne and Mercier sub-catchments (Yzeron catchment, France). $\mathrm{PhD}$ thesis, Université de Grenoble, pp. 321.

Jenson S, K Domingue JO. 1988. Extracting topographic structure from digital elevation data for geographic information system analysis. Photogrammetric engineering and remote sensing 54(11): 1593-1600.

Jones JA, Swanson FJ, Wemple BC, Snyder KU. 2000. Effects of roads on hydrology, geomorphology and disturbance patches in stream networks. Conservation Biology 14(1): 7685 .

Kenny, F Matthews B. 2005. A methodology for aligning raster flow direction data with photogrammetrically mapped hydrology. Computers and Geosciences 31: 768-779.

Lafont M, Vivier A, Nogueira S, Namour P, Breil P. 2006. Surface and hyporheic oligochaete assemblages in a French suburban stream. Hydrobiologia 564: 183-193. DOI 10.1007/s10750-005-1718-8.

Lea NL. 1992. An aspect driven kinematic routing algorithm. In: Overland Flow: Hydraulics and Erosion Mechanics, Parsons AJ, Abrahams AD (eds). Chapman \& Hall: New York, BY; 393-407.

Lhomme J, Bouvier C, Perrin JL. 2004. Applying a GIS-based geomorphological routing model in urban catchments. Journal of Hydrology 299(3-4): 203-216.

MacNutt W, Dare P, Dalton S. 2004. Use of digital terrain model as a means of urban watershed delineation in Fredericton, New Brunswick. Geomatica 58(2): 107-119.

Maidment D. 1996. GIS and hydrological modelling: an assessment of progress. In: Third International Conference on GIS and Environmental Modelling, Santa Fe, NM, 20-25 January 1996.

Michel C. 2009. Exploitation des données de deux sous-bassins versants de l'Yzeron : la Chaudanne et le Mercier. Rapport de Stage de Master 1 Sciences de l'Eau dans l'Environnement Continental effectué au Cemagref Lyon. Université des Sciences et Techniques du Languedoc Montpellier II, pp. 32.

Mitchell VG, Diaper C. 2005. Simulating the urban water and contaminant cycle. Environmental Modelling and Software 21: 129-134.

Moore ID, Grayson RB. 1991. Terrain-based catchment partitioning and runoff prediction using vector elevation data. Water Resources Research 27 (6): 1177-1191.

Murphy PNC, Ogilvie J, Meng FR, Arp P. 2008. Stream network modelling using LiDAR and photogrammetric digital elevation models: a comparison and field verification. Hydrological Processes 22: 1747-1754.

Nie L, Schilling W, Killingtveit A, Saegrov S, Selseth I. 2002. GIS based urban drainage analyses and their preliminary applications in urban stormwater management. Proceedings of $9^{\text {th }}$ International Conference On Urban Drainage (CD-ROM). Strecker EW, Huber WC (eds). ASCE, Reston, Va. 1-13. 
Niemczynowicz J. 1999. Urban hydrology and water management - present and future challenges. Urban Water 1: 1-14.

O'Callaghan JF, Mark DM. 1984. The Extraction of Drainage Networks From Digital Elevation Data. Computer Vision, Graphics and Image Processing 28: 328-344.

OTHU Field observatory for urban water management, 2010. http://www.graie.org/othu/. Consulted on 2010/9/16.

Quinn P, Beven K, Chevallier P, Planchon O. 1991. The prediction of hillslope flow paths for distributed hydrological modelling using digital terrain models. Hydrological Processes 5: 5979 .

Rodriguez F, Andrieu H, Creutin JD. 2003. Surface runoff in urban catchments: Morphological identification of unit hydrographs from urban databanks. Journal of Hydrology 283(1-4): 146-168.

Rodriguez F, Cudennec C, Andrieu H. 2005. Application of morphological approaches to determine unit hydrographs of urban catchments. Hydrological Processes 19(5): 1021-1035.

Rodriguez F, Andrieu H, Morena F. 2008. A distributed hydrological model for urbanized areas - Model development and application to case studies. Journal of Hydrology 351: 268287.

Runman N, Lin G, Li J. 2005. Investigation of GIS-based Surface Hydrological Modelling for Identifying Infiltration Zones in an Urban Watershed. Environmental Informatics Archives 3: 315-322.

Sarrazin B. 2012. Approches spatiales pour décrire le réseau de drainage et suivre sa dynamique de fonctionnement en milieu rural dans une perspective d'aide à la modélisation hydrologique. PhD thesis, Université de Grenoble, pp262.

Saunders W. 2000. Preparation of DEMs for use in environmental modelling analysis. Hydrologic and Hydraulic Modeling Support with Geographic Information Systems, Djokic D., Maidment D.R. (eds.), ESRI Press, Redlands, CA, 29-52.

SIRA, 2010. Sol Info Rhône-Alpes, sira@rhone-alpes.chambagri.fr - http://www.rhonealpes.chambagri.fr/sira/. Consulted on 2010/09/14.

Smith MB. 1993. A GIS-based distributed parameter hydrologic model for urban areas. Hydrological Processes 7: 45-61.

Smith MB, Vidmar A. 1994. Data Set Derivation for GIS-based Urban Hydrological Modeling. Photogrammetric Engineering and Remote Sensing 60(1): 67-76.

Smith MB. 2006. Comment on 'Analysis and modelling of flooding in urban drainage systems'. Journal of Hydrology 317: 355-363. 
Tarboton GD. 1997. A new method for the determination of flow directions and upslope areas in grid digital elevation models. Water Resources Research 33(2): 309-319.

Tarboton G.D. 2008. TAUDEM Terrain Analysis Using Digital Elevation Model. Software description. User Guide. Utah State University.

http://hydrology.neng.usu.edu/taudem/taudem3.1/index.html.

Vertessy RA, Hatton TJ, O'shaughnessy PJ, Jayasuriya MDA. 1993. Predicting water yield from a mountain ash forest catchment using a terrain analysis based catchment model. Journal of Hydrology 150: 665-700.

Vaze J., Teng J., Spencer G. 2010. Impact of DEM accuracy and resolution on topographic indices. Environmental Modelling \& Software 25:1086-1098.

Zech Y, Sillen X, Debources C, Van Hauwaert A. 1994. Rainfall-runoff modelling of partly urbanized watersheds: Comparison between a distributed model using GIS and other models sensitivity analysis. Water Sciences Technology 29(1-2): 163-170.

Zheng PQ, Baetz BW. 1999. GIS-based analysis of development options from a hydrology perspective. Journal of urban planning and development 125(4): 164-180. DOI: 10.1061/(ASCE)0733-9488(1999)125:4(164). 